\title{
Emergence of Pathogenic Strains of Staphylococcus aureus in Goat Milk and Their Comparative Response to Antibiotics
}

Iqra Muzammil', Muhammad Ijaz Saleem', Amjad Islam Aqib ${ }^{2, *}$, Ambreen Ashar ${ }^{3}$, Syed Ashar Mahfooz ${ }^{1}$, Sajjad ur Rahman ${ }^{4}$, Muhammad Shoaib ${ }^{4}$, Muhammad Aamir Naseer ${ }^{1}$, Imran Khan Sohrani ${ }^{1}$, Javeed Ahmad ${ }^{1}$, Razaullah Saqi ${ }^{1}$, Fizzah Laeeq Lodhi ${ }^{1}$ and Qaisar Tanveer ${ }^{5}$

${ }^{1}$ Department of Clinical Medicine and Surgery, Faculty of Veterinary Science, University of Agriculture, Faisalabad-38000

${ }^{2}$ Department of Medicine, Faculty of Veterinary Science, Cholistan University of Veterinary and Animal Sciences, Bahawalpur-63100

${ }^{3}$ Government College for Women University, Faisalabad-38000

${ }^{4}$ Institute of Microbiology, Faculty of Veterinary Science, University of Agriculture, Faisalabad-38000

${ }^{5}$ Institute of Pharmacy, Physiology and Pharmacology, University of Agriculture, Faisalabad-38000

\section{A B S T R A C T}

The nutraceutical milk of goat in agrobased countries is at risk of contamination with pathogenic strains of Staphylococcus aureus. The current study was designed to investigate prevalence of pathogenic strains of $S$. aureus, assessment of risk factors, and in-vitro antibiogram of non-biofilm producing $S$. aureus (nbpSA) and biofilm positive $S$. aureus (bpSA) from mastitic goats. The purposive sampling technique was applied to collect $n=200$ milk samples from different regions of goat populated areas of district FaisalabadPakistan. Using surf field mastitis test, collected milk samples were screened for subclinical mastitis at the spot for subsequent identification of pathogenic strains of $S$. aureus through microbiological examination in the laboratory. Non-probability statistical tools conferred $42 \%(84 / 200, \mathrm{CI}=35.37-48.93)$ prevalence of subclinical mastitis, $38.1 \% \mathrm{~S}$. aureus $(32 / 84, \mathrm{CI}=28.45-48.79), 15.6 \% \mathrm{MRSA}(5 / 32, \mathrm{CI}=6.87-31.76)$, $46.9 \%$ haemolytic $S$. aureus $(15 / 32$, $\mathrm{CI}=30.87-63.56)$ and $34.4 \%$ biofilm producing $S$. aureus $(11 / 32$, $\mathrm{CI}=20.41-51.69)$. Earthen floor type $(\mathrm{OR}=1.75, p=0.0996)$, poor drainage system $(\mathrm{OR}=7.33, p=0.002)$, pond as source of drinking water $(\mathrm{OR}=2.05, p=0.179)$, stall feeding $(\mathrm{OR}=7.27, p<0.001)$, 4-6 years of age of goat $(\mathrm{OR}=4.2, p=0.0874)$, and teat injury $(\mathrm{OR}=13.74, p<0.001)$ were potential risk factors for subclinical mastitis. The in-vitro findings of current study revealed $100 \%$ sensitivity of $S$. aureus against gentamicin, oxytetracycline, amoxicillin, and linezolid while $80 \%$ of biofilm negative $S$. aureus (nbpSA) showed sensitivity against amoxicillin+clavulanic acid. None of the isolate from bpSA and nbpSA was resistant against linezolid, gentamicin, and oxytetracycline in this study. bpSA were highly resistant against amoxicillin and vancomycin. The study found higher prevalence of pathogenic strains of $S$. aureus, higher number of potential risk factors, and diversified responses to antibiotic.

\section{INTRODUCTION}

L ivestock plays an important role in the agriculture sector of Pakistan. The total goat population of Pakistan is up to 74.1 million to produce 0.915 million tons of milk and 0.717 million tons of mutton annually (Anonymous, 2018). Milk production in goats is an active and emergent business in harsh climate areas where large ruminants cannot be reared or are difficult to rear

\footnotetext{
* Corresponding author: amjadwaseer@gmail.com 0030-9923/2021/0005-1659 \$ 9.00/0

Copyright 2021 Zoological Society of Pakistan
}

\begin{tabular}{l} 
Article Information \\
Received 24 October 2019 \\
Revised 22 May 2020 \\
Accepted 20 August 2020 \\
Available online 16 June 2021 \\
Authors' Contribution \\
\hline MIS, AIA and SUR designed the \\
research. AA and SAM supervised \\
the research. IKS, RS and JA did \\
sampling. IM and MAN did lab work \\
and wrote the article. MS analyzed \\
the data statistically. FLL and QT \\
review the article. \\
Key words \\
Goat, Mastitis, S. aureus, Biofilm, Risk \\
factors, Antibiogram.
\end{tabular}

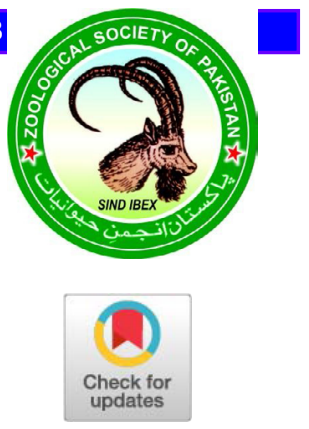


Samad, 2011). Sub-clinical mastitis has occurrence of $45 \%$ in goats in Punjab whereas 53.3\% in Khyber-Pakhtunkhwa (KPK), Pakistan (Najeeb et al., 2013; Ali et al., 2010).

Subclinical mastitis in goats is predominantly caused by transmissible bacteria e.g. Staphylococcus spp., Streptococcus spp., Pasteurella spp. and E. coli (Persson and Olofsson, 2011; Contreras et al., 2007). Staphylococcus aureus is the major causative agent where its frequency of isolation and identification vary from $4-40 \%$ of the entire isolated pathogens (Leitner et al., 2007). Antimicrobial resistance is reported in S. aureus probably due to excessive administration of antimicrobials (overprescription, suboptimal termination of treatment regimen and/or insufficient dose administration of antimicrobials) resulting in lateral gene transfer (transformation, transduction and conjugation) of DNA from resistant strain for survivability (Castro-Sánchez et al., 2016). S. aureus can produce biofilm which act as a protective layer for the pathogen and provides continuous persistence via development of resistant genes e.g. mecA, vanA, icaA, icaB etc. (Jyothi et al., 2018). Production ability of coagulase enzyme is considered a significant phenotypic determinant in $S$. aureus linked with pathogenicity (Moreillon et al., 1995). Multiple drug resistance (MDR) is one of additional challenges in bacterial mastitis (Hameed et al., 2007). In 1972, first MRSA was isolated from dairy mastitic milk (Devriese et al., 1972). MRSA is now becoming major bacterial etiology of mastitis in addition to its isolation from vaginal and nasal swabs of animals (Cortimiglia et al., 2015).

Treatment with broad spectrum antibiotics along with anti-inflammatory drugs is used to treat mastitis in goats. Mechanism of development of drug resistance in bacteria associated with goat mastitis is very important to understand transmission frequency, better management strategies and developing valuable remedial interference (Aqib et al., 2018a; Merz et al., 2016). Therefore, epidemiological studies of pathogenic strains of S. aureus along with their response to antibiotics are necessary for prevention and treatment protocols. Subclinical mastitis in goats remained as neglected issue despite of its increasing prevalence and antimicrobial resistance of bacterial etiologies. Current study was thus designed to investigate the occurrence of different pathogenic strains of S. aureus, associated risk factors, and in-vitro antibiogram of biofilm positive and biofilm negative $S$. aureus in mastitic goats from Faisalabad, Pakistan.

\section{MATERIALS AND METHODS}

Sampling plan and screening for subclinical mastitis

Faisalabad is the second biggest city of province
Punjab and the third most populated city of Pakistan having a total area of $5,856 \mathrm{~km}^{2}$. Purposive sampling technique (Thrusfield, 2007) was applied to collect milk samples $(n=200)$ from dairy farms located in district Faisalabad (Samundri, $n=62$; Rasoolpur, $n=60$; Livestock Farm of University of Agriculture Faisalabad, $n=36$; Jhapal, $n=42$ ) depending upon the willingness of the farmers to participate in the study and accessibility to Mastitis Research Laboratory, University of Agriculture Faisalabad, Pakistan. Milk samples were collected by strictly following the guidelines of National Mastitis Council of the USA (Reyher and Dohoo, 2011). Samples were screened by using Surf Field Mastitis test (SFMT) proposed by Muhammad et al. (2010). The SFMT positive milk samples, maintained in cold chain $\left(4^{\circ} \mathrm{C}\right)$, were transferred to Mastitis Research Laboratory, University of Agriculture Faisalabad, Pakistan and preserved at $-20^{\circ} \mathrm{C}$ till further process (Cengiz et al., 2015).

\section{Risk factor analysis}

A questionnaire comprising information like age of animal, type of housing, type of drainage system, type of floor, condition of floor, farm hygiene, source of drinking water, feeding system, vaccination against diseases, deworming, mastitis control program, parity number, stage of lactation, body condition score, milk consistency, milk yield, and teat injury was filled at the time of sampling to assess risk factors associated with mastitis. The risk factors were assumed based on the previous studies conducted by Amin et al. (2011) and Megersa et al. (2010).

\section{Identification of pathogenic strains of $\mathrm{S}$. aureus}

SFMT positive samples were cultured on blood agar at $37^{\circ} \mathrm{C}$ for $24 \mathrm{~h}$. Characteristic pinpoint colonies were further cultured on Mannitol Salt Agar, selective and differential medium for $S$. aureus, following the same incubation conditions. Series of biochemical tests were performed following guidelines of Bergey's Manual of Determinative Bacteriology (Bergey and Holt, 1994).

Isolates were identified for their expression as $\alpha, \beta$ and $\gamma$ haemolysis on blood agar by inoculating $S$. aureus on blood agar at $37^{\circ} \mathrm{C}$ for $24 \mathrm{~h}$. Methicillin resistant $S$. aureus were identified by their resistance against oxacillin disc following standard protocol described in clinical and laboratory standard institute. Biofilm was identified by Congo Red Agar (CRA) method, a previously established method (Freeman et al., 1989). For biofilm identification, fresh culture of $S$. aureus was grown on CRA and incubated for $24 \mathrm{~h}$ at $37^{\circ} \mathrm{C}$. After incubation, colour of colonies indicated strength of biofilm i.e. pinkish red colonies no biofilm production; slight blackish -weak production; black sheeting - moderate production; and jet black dry 
sheeting - strong biofilm production (França et al., 2012; Mathur et al., 2006).

In-vitro drug response against bpSA and nbpSA

In-vitro drug response was evaluated using the Kirby Bauer disc diffusion test. The positive isolates were subjected to testing against various antibiotics such as vancomycin $(30 \mu \mathrm{g})$, chloramphenicol $(10 \mu \mathrm{g})$, oxytetracycline $(30 \mu \mathrm{g})$, trimethoprim + sulphamethoxazole $(25 \mu \mathrm{g})$, gentamicin $(10 \mu \mathrm{g})$, linezolid $(30 \mu \mathrm{g})$, amoxicillinclavulanic acid $(20 \mu \mathrm{g})$, amoxicillin $(10 \mu \mathrm{g})$, and oxacillin $(1 \mu \mathrm{g})$. Fresh cultures adjusted at $1.5 \times 10^{8} \mathrm{CFU}$ were swabbed on Muller Hinton Agar whereas antibiotic discs were aseptically placed at equal distances from each other following the guidelines of CLSI (2015). Incubation was given at $37^{\circ} \mathrm{C}$ for $18-20 \mathrm{~h}$ and zone of inhibitions were measured by Vernier Callipers in millimetres and compared with provided standards.

\section{Statistical analysis}

The obtained data were analysed by descriptive statistics for occurrence of $S$. aureus and antibacterial activity of antibiotics whereas risk factor analysis was assessed by odd's ratio at 5\% probability using IBM SPSS (version 20).

\section{RESULTS}

Prevalence of subclinical mastitis and pathogenic strains of $\mathrm{S}$. aureus

The present study found overall $42.0 \%$ (84/200) prevalence of subclinical mastitis from goats based on Surf Field Mastitis Test (SFMT). The prevalence of subclinical mastitis was found higher in Jhapal (59.5\%) followed by Samundri (38.7\%), Rasoolpur (38.3\%) and UAF Livestock Farm $(33.3 \%)$ while there was non-significant association ( $p>0.05$ ) among different areas. The overall prevalence of $S$. aureus was found $38.1 \%$ while among $S$. aureus there was $15.6 \%$ MRSA, $46.9 \%$ haemolytic $S$. aureus, $34.4 \%$ biofilm producing $S$. aureus during current study. The higher prevalence of $S$. aureus and MRSA was noted from livestock farm (50.0\% and 33.3\%) followed by Samundri (33.3\% and $12.5 \%)$, Rasoolpur (39.1\% and $11.1 \%)$ and Jhapal $(36.0 \%$ and $11.1 \%)$. The percentage of haemolytic $S$. aureus and biofilm producing $S$. aureus was $83.3 \%$ and $83.3 \%$ from UAF livestock farm, $44.4 \%$ and $33.3 \%$ from Rasoolpur, $37.5 \%$ and $12.5 \%$ from Samundri, and $33.3 \%$ and $22.2 \%$ from Jhapal, respectively. The study found non-significant difference $(p>0.05)$ for $S$. aureus, MRSA and haemolytic $S$. aureus while significant difference was noted for biofilm producing $S$. aureus among different areas of study (Table I; Fig. 1).

Table I.- Prevalence of subclinical mastitis, Staphylococcus aureus, methicillin resistant S. aureus, hemolytic and biofilm producing Staphylococci from different areas of Faisalabad.

\begin{tabular}{|c|c|c|c|c|c|c|}
\hline Area & & $\begin{array}{c}\text { Subclinical mastitis } \\
\text { (SM) on SFMT basis* }\end{array}$ & $\begin{array}{c}\text { Staphylococcus } \\
\text { aureus }^{\#}\end{array}$ & $\begin{array}{c}\text { Methicillin resistant } \\
\text { S. aureus within } \\
\text { S. aureus }\end{array}$ & $\begin{array}{l}\text { Haemolytic } \\
\text { S. aureus }{ }^{@}\end{array}$ & $\begin{array}{l}\text { Biofilm producing } \\
\text { S. aureus }{ }^{\dagger}\end{array}$ \\
\hline \multirow[t]{3}{*}{ Samundri } & No. observed & $24 / 62$ & $8 / 24$ & $1 / 8$ & $3 / 8$ & $1 / 8$ \\
\hline & Prevalence $(\%)$ & 38.7 & 33.3 & 12.5 & 37.5 & 12.5 \\
\hline & CI $(95 \%)$ & $27.58-51.15$ & $17.97-53.29$ & $2.24-47.09$ & $13.68-69.43$ & $2.24-47.09$ \\
\hline \multirow[t]{3}{*}{ Rasoolpur } & No. observed & $23 / 60$ & $9 / 23$ & $1 / 9$ & $4 / 9$ & $3 / 9$ \\
\hline & Prevalence $(\%)$ & 38.3 & 39.1 & 11.1 & 44.4 & 33.3 \\
\hline & CI $(95 \%)$ & $27.09-50.98$ & $22.16-59.21$ & $1.99-43.50$ & $18.87-73.33$ & $12.06-64.58$ \\
\hline \multirow{3}{*}{$\begin{array}{l}\text { UAF livestock } \\
\text { farm }\end{array}$} & No. observed & $12 / 36$ & $6 / 12$ & $2 / 6$ & $5 / 6$ & $5 / 6$ \\
\hline & Prevalence $(\%)$ & 33.3 & 50.0 & 33.3 & 83.3 & 83.3 \\
\hline & CI (95\%) & $20.21-49.66$ & $25.38-74.62$ & $9.68-70.00$ & 43.65-96.99 & 43.65-96.99 \\
\hline \multirow[t]{3}{*}{ Jhapal } & No. observed & $25 / 42$ & $9 / 25$ & $1 / 9$ & $3 / 9$ & $2 / 9$ \\
\hline & Prevalence $(\%)$ & 59.5 & 36.0 & 11.1 & 33.3 & 22.2 \\
\hline & CI $(95 \%)$ & $44.49-72.95$ & $20.25-55.48$ & $2.24-47.09$ & $12.06-64.58$ & $6.32-54.74$ \\
\hline \multirow[t]{3}{*}{ Total } & No. observed & $84 / 200$ & $32 / 84$ & $5 / 32$ & $15 / 32$ & $11 / 32$ \\
\hline & Prevalence $(\%)$ & 42.0 & 38.1 & 15.6 & 46.9 & 34.4 \\
\hline & CI $(95 \%)$ & $35.37-48.93$ & $28.45-48.79$ & $6.87-31.76$ & $30.87-63.56$ & $20.41-51.69$ \\
\hline
\end{tabular}

$p<0.05$ indicate significant difference. Among different areas subclinical mastitis, ${ }^{*}, p=0.072 ;{ }^{*}, p=0.799$ and ${ }^{\ddagger}, p=0.623 ;{ }^{@}, p=0.244 ;{ }^{\dagger}, p=0.034$. 
Table II.- Risk factors associated with spread of mastitis in dairy goats.

\begin{tabular}{|c|c|c|c|c|c|c|}
\hline Factor & Variables & No. positive & Percentage (\%) & Odds ratio & C.I (95\%) & $p$-value \\
\hline \multirow[t]{3}{*}{ Housing type } & Open & $29 / 80$ & 36.25 & 1.093 & $0.49-2.46$ & 0.829 \\
\hline & Street & $13 / 38$ & 34.21 & 1 & - & - \\
\hline & Backyard & $42 / 82$ & 51.21 & 2.019 & $0.91-4.48$ & 0.084 \\
\hline \multirow[t]{3}{*}{ Floor type } & Earthen & $40 / 80$ & 50.00 & 1.75 & $0.90-3.41$ & 0.099 \\
\hline & Bricks & $20 / 54$ & 37.03 & 1.029 & $0.49-2.17$ & 0.939 \\
\hline & Cemented & $24 / 66$ & 36.36 & 1 & - & - \\
\hline \multirow[t]{2}{*}{ Condition of floor } & Even & $56 / 120$ & 46.67 & 1.625 & $0.91-2.91$ & 0.102 \\
\hline & Uneven & $28 / 80$ & 35.00 & 1 & - & - \\
\hline \multirow[t]{3}{*}{ Drainage system } & Poor & $16 / 24$ & 66.67 & 7.333 & $2.54-21.21$ & 0.0002 \\
\hline & Partially controlled & $56 / 120$ & 46.67 & 3.208 & $1.54-6.67$ & 0.002 \\
\hline & Well formed & $12 / 56$ & 21.42 & 1 & - & - \\
\hline \multirow[t]{4}{*}{ Farm hygiene } & Very poor & $9 / 32$ & 28.13 & 0.671 & $0.24-1.85$ & 0.44 \\
\hline & Poor & $17 / 40$ & 42.5 & 1.267 & $0.51-3.15$ & 0.61 \\
\hline & Normal & $44 / 90$ & 48.89 & 1.64 & $0.75-3.57$ & 0.213 \\
\hline & Good & $14 / 38$ & 36.84 & 1 & - & - \\
\hline \multirow{3}{*}{$\begin{array}{l}\text { Source of } \\
\text { drinking water }\end{array}$} & Pond & $9 / 16$ & 56.25 & 2.047 & $0.72-5.82$ & 0.179 \\
\hline & Underground & $21 / 44$ & 47.72 & 1.454 & $0.73-2.88$ & 0.282 \\
\hline & Bucket & $54 / 140$ & 38.57 & 1 & - & - \\
\hline \multirow[t]{3}{*}{ Feeding } & Grazing & $27 / 100$ & 27.00 & 1 & - & - \\
\hline & Stall feeding & $35 / 48$ & 72.92 & 7.279 & $3.35-15.80$ & $<0.0001$ \\
\hline & Mixed & $22 / 52$ & 42.31 & 1.983 & $0.98-4.01$ & 0.057 \\
\hline \multirow{2}{*}{$\begin{array}{l}\text { Vaccinated } \\
\text { against diseases }\end{array}$} & Yes & $25 / 124$ & 20.16 & 2.467 & $1.23-4.95$ & 0.011 \\
\hline & No & $59 / 76$ & 77.63 & 1 & - & - \\
\hline \multirow[t]{2}{*}{ Deworming } & Yes & $53 / 128$ & 41.41 & 1 & - & - \\
\hline & No & $31 / 72$ & 43.05 & 1.069 & $0.60-1.92$ & 0.82 \\
\hline \multirow{2}{*}{$\begin{array}{l}\text { Mastitis control } \\
\text { measures }\end{array}$} & Yes & $30 / 76$ & 39.47 & 1 & - & - \\
\hline & No & $54 / 124$ & 43.55 & 1.183 & $0.66-2.11$ & 0.571 \\
\hline \multirow[t]{5}{*}{ Age } & Up to 2 years & $13 / 42$ & 31.0 & 3.138 & $0.62-15.85$ & 0.166 \\
\hline & $2-4$ years & $29 / 102$ & 28.4 & 2.781 & $0.59-13.01$ & 0.194 \\
\hline & 4-6 years & $12 / 32$ & 37.5 & 4.2 & $0.81-21.77$ & 0.087 \\
\hline & $6-8$ years & $2 / 16$ & 12.5 & 1 & - & - \\
\hline & Above 8 years & $1 / 8$ & 12.5 & 1 & $0.08-13.02$ & 1 \\
\hline \multirow[t]{3}{*}{ Parity } & 1-2 kidding & $27 / 49$ & 55.10 & 0.859 & $0.28-2.63$ & 0.79 \\
\hline & 2-4 kidding & $20 / 34$ & 58.82 & 1 & $0.31-3.26$ & 1 \\
\hline & $>5$ kidding & $10 / 17$ & 58.82 & 1 & - & - \\
\hline \multirow[t]{3}{*}{ Stage of lactation } & Early & $23 / 42$ & 54.76 & 1 & - & - \\
\hline & Mid & $12 / 23$ & 52.17 & 0.901 & $0.33-2.50$ & 0.841 \\
\hline & Late & $22 / 35$ & 62.86 & 1.398 & $0.56-3.49$ & 0.473 \\
\hline \multirow{3}{*}{$\begin{array}{l}\text { Body condition } \\
\text { score (BCS) }\end{array}$} & Poor & $29 / 47$ & 61.70 & 1.381 & $0.40-4.77$ & 0.609 \\
\hline & Normal & $20 / 40$ & 50.00 & 0.857 & $0.24-3.00$ & 0.809 \\
\hline & Good & $7 / 13$ & 53.84 & 1 & - & - \\
\hline \multirow[t]{3}{*}{ Milk consistency } & Thin & $70 / 165$ & 42.42 & 1.228 & $0.51-2.97$ & 0.648 \\
\hline & Thick & $9 / 24$ & 37.50 & 1 & - & - \\
\hline & Purulent & $5 / 11$ & 45.45 & 1.389 & $0.33-5.90$ & 0.656 \\
\hline \multirow[t]{2}{*}{ Milk yield } & Decreased & $27 / 45$ & 60.00 & 1.25 & $0.56-2.78$ & 0.584 \\
\hline & Not Decreased & $30 / 55$ & 54.54 & 1 & - & - \\
\hline \multirow[t]{2}{*}{ Teat injury } & Yes & $59 / 76$ & 77.63 & 13.743 & $6.86-27.55$ & $<0.0001$ \\
\hline & No & $25 / 124$ & 20.16 & 1 & - & - \\
\hline
\end{tabular}

C.I, confidence interval set at $95 \% ;{ }^{*} p<0.05$ indicate significant difference. 


\section{Risk factor analysis}

The findings of the current study presented type of drainage system, type of feeding, vaccination against diseases, and teats injury as potential risk factors $(p<$ $0.05)$ of subclinical mastitis. Poor type of drainage system $(p=0.0002)$ and stall feeding $(p<0.0001)$ showed higher odds of getting mastitis compared to partially controlled drainage system $(p=0.0018)$ and mixed feeding $(p=$ 0.0572 ), respectively. The risk factor analysis revealed backyard type of housing showing higher odds of getting mastitis ( $p=0.0843)$ as compared to open type of housing $(p=0.8289)$. Similar findings were found in case of earthen type of floor ( $p=0.0996)$ as compared to brick floor ( $p=$ $0.9393)$. Mid stage of lactation $(p=0.8414), 1-2$ kidding ( $p=0.7900)$, normal body condition scoring $(p=0.8096)$ were not proved to be potential risk factors of subclinical mastitis (Table II).

Antibiotic Susceptibility testing against S. aureus and biofilm producing S. aureus

The in-vitro findings of current study revealed $100 \%$ sensitivity of $S$. aureus against gentamicin, oxytetracycline, amoxicillin, and linezolid while $80 \%$ of biofilm negative S. aureus (nbpSA) showed sensitivity against amoxicillin + clavulanic acid (Table III; Fig. 1). Higher percentages of goat milk based resistant isolates were noted from bpSA and nbpSA against vancomycin, chloramphenicol, oxacillin, amoxicillin+clavulanic acid and amoxicillin. None of the isolate from bpSA and nbpSA was resistant against linezolid, gentamicin, and oxytetracycline in this study. In case of oxacillin, amoxicillin clavulanate and trimethoprim+sulphamethoxazole there was significant $(p<0.05)$ difference at intermediate cadre, and same was observed at sensitive cadre of isolates. The antibiotics did not differ significantly in efficacies between sensitive bpSA strains and sensitive nbpSA strains (Table III).

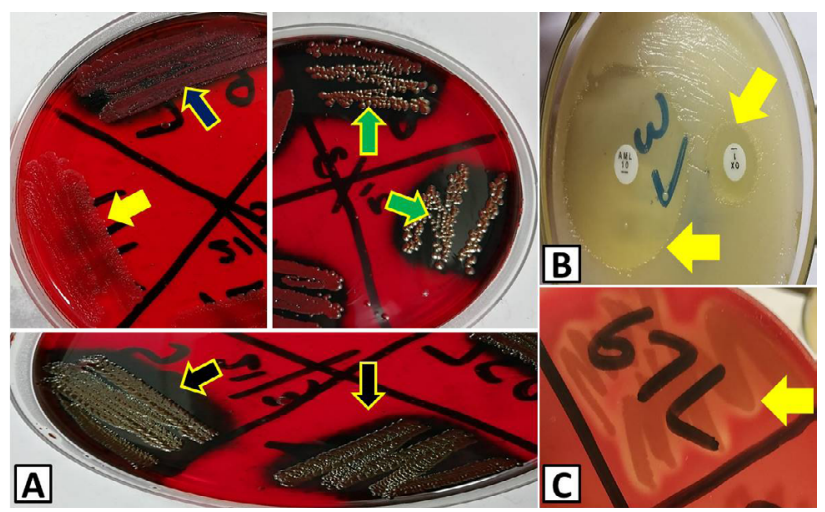

Fig. 1. Biofilm producing strains, response of $S$. aureus against antibiotics and haemolytic strains. A, arrows point out different kinds of biofilm: yellow arrow, no biofilm; blue arrow, weak biofilm; green arrows, moderate biofilm; black arrow, strong biofilm. B, zone of inhibitions produced by antibiotics against $S$. aureus (yellow arrows, zones of inhibition). C, haemolysis on blood agar produced by $S$. aureus (yellow arrow, partial haemolysis).

\section{DISCUSSION}

Prevalence of subclinical mastitis, S. aureus, MRSA, hemolytic and biofilm producing $\mathrm{S}$. aureus

The prevalence of subclinical mastitis in current study was in line with findings of Najeeb et al. (2013) who reported $45 \%$ subclinical mastitis from goats. On the other hands, $37.5 \%$ and $53 \%$ subclinical mastitis in goats was also noted in previous studies by Abo-Shama (2014) and Ali et al. (2010). S. aureus has been formerly described

Table III.- Comparative response of antibiogram of biofilm producing and non-biofilm producing $S$. aureus isolated from mastitic dairy goats.

\begin{tabular}{|c|c|c|c|c|c|c|c|c|c|}
\hline \multirow[t]{2}{*}{ Antibiotic } & \multicolumn{3}{|c|}{ Resistant \% } & \multicolumn{3}{|c|}{ Intermediate \% } & \multicolumn{3}{|c|}{ Sensitive $\%$} \\
\hline & NBPSA & BPSA & p-value & NBPSA & BPSA & p-value & NBPSA & BPSA & p-value \\
\hline Vancomycin & 20 & 57.14 & 0.021 & 40 & 42.86 & 0.014 & 40 & 0 & 0.064 \\
\hline Oxacillin & 40 & 0.000 & 0.383 & 40 & 14.29 & 0.036 & 20 & 85.71 & 0.057 \\
\hline Amoxicillin+Clavulanic acid & 0 & 42.86 & 0.322 & 20 & 0 & 0.024 & 80 & 57.14 & 0.026 \\
\hline Linezolid & 0 & 0 & N/A & 0 & 28.57 & 0.787 & 100 & 71.43 & 0.035 \\
\hline Gentamicin & 0 & 0 & N/A & 0 & 0 & N/A & 100 & 100 & N/A \\
\hline $\begin{array}{l}\text { Trimethoprim }+ \\
\text { Sulphamethoxazole }\end{array}$ & 20 & 0 & 0.689 & 40 & 0 & 0.044 & 40 & 100 & 0.056 \\
\hline Oxytetracycline & 0 & 0 & N/A & 0 & 0 & N/A & 100 & 100 & 0.457 \\
\hline Chloramphenicol & 40 & 14.29 & 0.047 & 40 & 14.29 & 0.047 & 2 & 71.43 & 0.037 \\
\hline Amoxicillin & 0 & 71.43 & 0.057 & 0 & 0 & N/A & 100 & 28.57 & 0.479 \\
\hline
\end{tabular}

NBPSA, non-biofilm producing $S$. aureus; BPSA, biofilm producing $S$. aureus; NA, not applicable. 
as one of the most significant causative agent in caprine mastitis (Ali et al., 2010; Najeeb et al., 2013). Higher biofilm positive $S$. aureus in current study was in contradiction with findings of França et al. (2012) who reported 7.6\% bpSA based on CRA from caprine milk.

Hemolysins are involved in various pathological processes. Kenny et al. (1992) reported that haemolytic toxins can develop clinical signs in mastitis cases, and Ebrahimi et al. (2007) reported that the udder of mastitic goats contain hemolytic Staphylococci. In the current study, $15.6 \%$ of $S$. aureus were found to be resistant to methicillin which was in line with the previous results of $9.2 \%$ as discussed by El-Deeb et al. (2018), $20 \%$ by Bochev and Russenova (2005), and $28.57 \%$ by Ebrahimi et al. (2007). The methicillin-resistant Staphylococci cannot be successfully treated with beta-lactam antibiotics as discussed by previous studies (Aqib et al., 2018b; Dar et al., 2006).

\section{Risk factors}

Potential risk factors of current study were in line with findings of previous studies conducted in Pakistan. Feeding system is significant factor for subclinical mastitis. Poor drainage system or farm hygiene can lead to occurrence of mastitis (Ali et al., 2010; Aqib et al., 2019; Najeeb et al., 2013). Teat injury is also strongly associated with mastitis (Ferdous et al., 2018). Wound on the teats and udder facilitates the entry of microbes into the glands, leading to mastitis (Gebrewahid et al., 2012). The findings of current study were in line with those of previous trials conducted on prevalence of subclinical mastitis in goats by Ali et al. (2010) and Najeeb et al. (2013).

\section{Antibiogram}

The results of current study were in line with those reported by Ali et al. (2010) and Saleem et al. (2018) who found $80-100 \%$ of $S$. aureus sensitive against these antibiotics. The decreased use of gentamicin in the late 1990's and obvious shift in strains of clinical isolates of $S$. aureus were major factors for increased gentamicin sensitivity (Klevens et al., 2006). Oxytetracycline is used as first line treatment by field workers. Oppliger et al. (2012) also suggested that $S$. aureus isolated from farm workers were $100 \%$ sensitive to oxytetracycline.

Vancomycin resistance is a rising problem in $S$. aureus isolates and their number is increasing day by day which may be due to the acquired resistance as occurred in case of methicillin (Marques et al., 2013). Glycopeptide antibiotics such as vancomycin are last choice for the severe clinical infections of MRSA throughout the world. But the continuous use of vancomycin for handling of MDR S. aureus infections has caused a decrease in vancomycin sensitivity in many countries (Hiramatsu et al., 1997; Rağbetli et al., 2016). Vancomycin resistance in S. aureus when studied at genomic level shows that the development of $v a n \mathrm{~A}$ gene is associated with this behaviour (Akpaka et al., 2017). Mastitis is well known for its deterioration and lack of response to treatment chiefly due to resistance by bacteria against antibiotics (Shamila-Syuhada et al., 2016).

\section{CONCLUSION}

The present study found overall higher prevalence of subclinical mastitis $(42 \%)$ in goats with increased percentage of S. aureus (3.8.1\%) and pathogenic strains of S. aureus (MRSA $15.6 \%$, hemolytic S. aureus $46.9 \%$, and biofilm producing $S$. aureus $34.4 \%$ ). Risk factor analysis revealed type of drainage system, type of feeding, and teats injury as potential risk factors of mastitis. The in-vitro drug trial indicated higher sensitivity of $S$. aureus against oxytetracycline, trimethoprim + sulphamethoxazole, gentamicin and linezolid against $S$. aureus and biofilm producing $S$. aureus. Biofilm producing $S$. aureus were highly resistant against amoxicillin and vancomycin. Current study reports higher prevalence of pathogenic strains of $S$. aureus, larger number of potential risk factors, and diversified response of antibiotic susceptibilities which suggest extensive molecular studies and development of effective preventive measures.

\section{Statement of conflict of interest}

The authors have declared no conflict of interest.

\section{REFERENCES}

Abo-Shama, U.H., 2014. Prevalence and antimicrobial susceptibility of Staphylococcus aureus isolated from cattle, buffalo, sheep and goats raws milk in Sohag governorate, Egypt. Assiut Vet. Med. J., 60: 141.

Akpaka, P.E., Roberts, R. and Monecke, S., 2017. Molecular characterization of antimicrobial resistance genes against Staphylococcus aureus isolates from Trinidad and Tobago. J. Infect. Publ. Hlth., 10: 316-323. https://doi.org/10.1016/j. jiph.2016.05.010

Ali, Muhammad, G., Ahmad, T., Khan, R., Anwar, H., Farooqi, F.A., Manzoor, M.N. and Usama, A.R., 2010. Prevalence of caprine sub-clinical Mastitis, its etiological agents and its sensitivity to antibiotics in indigenous breeds of Kohat, Pakistan. Pakistan J. Life Soc. Sci., 8: 63-67.

Amin, M.A., Samad, M.A. and Rahman, A.K.M.A., 
2011. Bacterial pathogens and risk factors associated with mastitis in Black Bengal goats in Bangladesh. Bangladesh J. vet. Med., 9: 155-159. https://doi.org/10.3329/bjvm.v9i2.13458

Anonymous, 2018. Pakistan economic survey 201718. Finance Division, Govt. of Pakistan. Available at: http://www.finance.gov.pk/survey_1718.html (Accessed on 20 August, 2020).

Aqib, A.I., Ijaz, M., Anjum, A.A., Malik, M.A.R., Mehmood, K., Farooqi, S.H. and Hussain, K., 2017. Antibiotic susceptibilities and prevalence of Methicillin resistant Staphylococcus aureus (MRSA) isolated from bovine milk in Pakistan. Acta Trop., 176: 168-172. https://doi.org/10.1016/j. actatropica.2017.08.008

Aqib, A., Ijaz, M., Farooqi, S. and Raza, A., 2018. Dairy Staphylococcus aureus: Epidemiology, drug susceptibilities, drug modulation, and preventive measures. In: Staphylococcus aureus (eds. H. Hemeg, H. Ozbak and F. Afrin). IntechOpen. https://doi.org/10.5772/intechopen.74552

Aqib, A.I., Anjum, A.A., Ijaz, M., Hussain, R., Ahmed, R., Farooqi, S.H., Aslam, H., Hussain, K., Mehmood, K. and Zhang, H., 2018a. Development and evaluation of vaccine against Staphylococcus aureus recovered from naturally occurring mastitis in she-camels. Microb. Pathog., 117: 341-347. https://doi.org/10.1016/j.micpath.2018.03.003

Aqib, A.I., Ijaz, M., Farooqi, S.H., Ahmed, R., Shoaib, M., Ali, M.M., Mehmood, K. and Zhang, H., 2018b. Emerging discrepancies in conventional and molecular epidemiology of methicillin resistant Staphylococcus aureus isolated from bovine milk. Microb. Pathog., 116: 38-43. https:// doi.org/10.1016/j.micpath.2018.01.005

Bergey, D.H. and Holt, J.G., 1994. Bergey's manual of determinative bacteriology. Williams and Wilkins, Baltimore, MA.

Bochev, I. and Russenova, N., 2005. Resistance of Staphylococcus spp. strains isolated from goats with subclinical mastitis. Bulgarian J. vet. Med., 8: 109-118

Castro-Sánchez, E., Moore, L.S.P., Husson, F. and Holmes, A.H., 2016. What are the factors driving antimicrobial resistance? Perspectives from a public event in London, England. BMC Infect. Dis., 16: 465. https://doi.org/10.1186/s12879-0161810-x

Cengiz, S., Dinc, G. and Cengiz, M., 2015. Evaluation of antimicrobial resistance in Staphylococcus Spp. isolated from subclinical mastitis in cows. Pakistan Vet. J., 35: 334-338.
CLSI, 2015. Performance standards for antimicrobial susceptibility testing. Twenty-Second Informational Supplement Clinical and Laboratory Standards Institute, CLSI document M100-S16CLSI, Wayne, PA.

Contreras, A., Luengo, C., Sanchez, A. and Corrales, J.C., 2003. The role of intramammary pathogens in dairy goats. Livest. Prod. Sci., 79: 273-283. https:// doi.org/10.1016/S0301-6226(02)00172-0

Contreras, A., Sierra, D., Sánchez, A., Corrales, J.C., Marco, J.C., Paape, M.J. and Gonzalo, C., 2007. Mastitis in small ruminants. Small Rumin. Res., 68: 145-153. https://doi.org/10.1016/j. smallrumres.2006.09.011

Cortimiglia, C., Bianchini, V., Franco, A., Caprioli, A., Battisti, A., Colombo, L., Stradiotto, K., Vezzoli, F. and Luini, M., 2015. Prevalence of Staphylococcus aureus and methicillin-resistant $S$. aureus in bulk tank milk from dairy goat farms in Northern Italy. $J$. Dairy Sci., 98: 2307-2311. https://doi.org/10.3168/ jds.2014-8923

Dar, J.A., Thoker, M.A., Khan, J.A., Ali, A., Khan, M.A., Rizwan, M., Bhat, K.H., Dar, M.J., Ahmed, N. and Ahmad, S., 2006. Molecular epidemiology of clinical and carrier strains of methicillin resistant Staphylococcus aureus (MRSA) in the hospital settings of north India. Annls clin. Microbiol. Antimicrob., 5: 22. https://doi.org/10.1186/14760711-5-22

Devriese, L.A., Van Damme, L.R. and Fameree, L., 1972. Methicillin (cloxacillin) resistant Staphylococcus aureus strains isolated from bovine mastitis cases. Z. Vet. Reihe B, 19: 598-605. https:// doi.org/10.1111/j.1439-0450.1972.tb00439.x

Ebrahimi, A., Lotfalian, S. and Karimi, S., 2007. Drug resistance in isolated bacteria from milk of sheep and goats with subclinical mastitis in Shahrekord district. Iranian J. vet. Res., 8: 76-79.

El-Deeb, W., Fayez, M., Elmoslemany, A., Kandeel, M. and Zidan, K., 2018. Methicillin resistant Staphylococcus aureus among goat farms in Eastern province, Saudi Arabia: Prevalence and risk factors. Prevent. vet. Med., 156: 84-90. https:// doi.org/10.1016/j.prevetmed.2018.05.005

Ferdous, J., Rahman, M.S., Khan, M.I., Khan, M. and Rima, U.K., 2018. Prevalence of clinical and subclinical caprine mastitis of northern region in Bangladesh. Progr. Agric., 29: 127-138. https://doi. org/10.3329/pa.v29i2.38296

França, C.A., Peixoto, R.M., Cavalcante, M.B., Melo, N.F., Oliveira, C.J.B., Veschi, J.L.A., Mota, R.A. and Costa, M.M., 2012. Antimicrobial resistance of 
Staphylococcus spp. from small ruminant mastitis in Brazil. Pesquisa Vet. Brasil., 32: 747-753. https:// doi.org/10.1590/S0100-736X2012000800012

Freeman, D.J., Falkiner, F.R. and Keane, C.T., 1989. New method for detecting slime production by coagulase negative Staphylococci. J. clin. Pathol., 42: 872-874. https://doi.org/10.1136/jcp.42.8.872

Gebrewahid, T.T., Abera, B.H. and Menghistu, H.T., 2012. Prevalence and etiology of subclinical mastitis in small ruminants of Tigray regional State, north Ethiopia. Vet. World, 5: 103-109. https://doi. org/10.5455/vetworld.2012.103-109

Goh, S.H., Byrne, S.K., Zhang, J.L. and Chow, A.W., 1992. Molecular typing of Staphylococcus aureus on the basis of coagulase gene polymorphisms. J. clin. Microbiol., 30: 1642-1645. https://doi. org/10.1128/JCM.30.7.1642-1645.1992

Hameed, K.G.A., Sender, G. and Korwin-Kossakowska, A., 2007. Public health hazard due to mastitis in dairy cows. Anim. Sci. Pap. Rep., 25: 73-85.

Hiramatsu, K., Aritaka, N., Hanaki, H., Kawasaki, S., Hosoda, Y., Hori, S., Fukuchi, Y. and Kobayashi, I., 1997. Dissemination in Japanese hospitals of strains of Staphylococcus aureus heterogeneously resistant to vancomycin. The Lancet, 350: 1670-1673. https://doi.org/10.1016/S0140-6736(97)07324-8

Jyothi, J.S., Putty, K., Reddy, Y.N., Dhanalakshmi, K. and Umair, M.A.H., 2018. Antagonistic effect of ursolic acid on Staphylococcal biofilms. Vet. World, 11: 1440. https://doi.org/10.14202/ vetworld.2018.1440-1444

Kenny, K., Bastida, F.D. and Norcross, N.L., 1992. Secretion of alpha-hemolysin by bovine mammary isolates of Staphylococcus aureus. Canadian J. vet. Res., 56: 265 .

Klevens, R.M., Edwards, J.R., Tenover, F.C., McDonald, L.C., Horan, T., Gaynes, R. and System, N.N.I.S., 2006. Changes in the epidemiology of methicillinresistant Staphylococcus aureus in intensive care units in US hospitals, 1992-2003. Clin. Infect. Dis., 42: 389-391. https://doi.org/10.1086/499367

Leitner, G., Merin, U., Lavi, Y., Egber, A. and Silanikove, N., 2007. Aetiology of intramammary infection and its effect on milk composition in goat flocks. $J$. Dairy Res., 74: 186-193. https://doi.org/10.1017/ S0022029906002299

Malinowski, E., Klossowska, A., Kaczmarowski, M., Lassa, H. and Kuzma, K., 2002. Antimicrobial susceptibility of staphylococci isolated from affected with mastitis cows. Bull. Vet. Inst. Pulawy, 46: 289-294.

Marques, J.B., Dalmolin, T.V., Bonez, P.C., Agertt,
V.A., Campos, M.M.A. and de Santos, R.C.V., 2013. Detection of Staphylococcus aureus with an intermediate profile to vancomycin (VISA) isolate from Santa Maria, RS. Brazilian J. Microbiol., 44: 277-279. https://doi.org/10.1590/S151783822013000100040

Mathur, T., Singhal, S., Khan, S., Upadhyay, D.J., Fatma, T. and Rattan, A., 2006. Detection of biofilm formation among the clinical isolates of staphylococci: An evaluation of three different screening methods. Indian J. med. Microbiol., 24: 25. https://doi.org/10.4103/0255-0857.19890

Megersa, B., Tadesse, C., Abunna, F., Regassa, A., Mekibib, B. and Debela, E., 2010. Occurrence of mastitis and associated risk factors in lactating goats under pastoral management in Borana, Southern Ethiopia. Trop. Anim. Hlth. Prod., 42: 1249-1255. https://doi.org/10.1007/s11250-010-9557-7

Merz,A., Stephan, R. and Johler, S., 2016. Staphylococcus aureus isolates from goat and sheep milk seem to be closely related and differ from isolates detected from bovine milk. Front. Microbiol., 7: 319. https:// doi.org/10.3389/fmicb.2016.00319

Moreillon, P., Entenza, J.M., Francioli, P., McDevitt, D., Foster, T.J., Francois, P. and Vaudaux, P., 1995. Role of Staphylococcus aureus coagulase and clumping factor in pathogenesis of experimental endocarditis. Infect. Immun., 63: 4738-4743. https://doi.org/10.1128/IAI.63.12.4738-4743.1995

Muhammad, G., Naureen, A., Asi, M.N., Saqib, M. and Fazal-ur-Rehman, 2010. Evaluation of a 3\% surf solution (surf field mastitis test) for the diagnosis of subclinical bovine and bubaline mastitis. Trop. Anim. Hlth. Prod., 42: 457-464. https://doi. org/10.1007/s11250-009-9443-3

Najeeb, M.F., Anjum, A.A., Ahmad, M.U.D., Khan, H.M., Ali, M.A. and Sattar, M.M.K., 2013. Bacterial etiology of subclinical mastitis in dairy goats and multiple drug resistance of the isolates. $J$. Anim. Pl. Sci., 23: 1541-1544.

Oliveira, M., Bexiga, R., Nunes, S.F., Carneiro, C., Cavaco, L.M., Bernardo, F. and Vilela, C.L., 2006. Biofilm-forming ability profiling of Staphylococcus aureus and Staphylococcus epidermidis mastitis isolates. Vet. Microbiol., 118: 133-140. https://doi. org/10.1016/j.vetmic.2006.07.008

Oppliger, A., Moreillon, P., Charrière, N., Giddey, M., Morisset, D. and Sakwinska, O., 2012. Antimicrobial resistance of Staphylococcus aureus strains acquired by pig farmers from pigs. Appl. environ. Microbiol., 78: 8010. https://doi. org/10.1128/AEM.01902-12 
Park, Y.W., 2001. Hypo-allergenic and therapeutic significance of goat milk. Fd. Sci. Indust., 34: 6-13.

Persson, Y. and Olofsson, I., 2011. Direct and indirect measurement of somatic cell count as indicator of intramammary infection in dairy goats. Acta Vet. Scand., 53: 15. https://doi.org/10.1186/1751-014753-15

Rağbetli, C., Parlak, M., Bayram, Y., Guducuoglu, H. and Ceylan, N., 2016. Evaluation of antimicrobial resistance in Staphylococcus aureus isolates by years. Interdiscip. Perspect. Infect. Dis., 2016: 9171395. https://doi.org/10.1155/2016/9171395

Reyher, K.K. and Dohoo, I.R., 2011. Diagnosing intramammary infections: Evaluation of composite milk samples to detect intramammary infections. $J$. Dairy Sci., 94: 3387-3396. https://doi.org/10.3168/ jds.2010-3907

Saleem, M.I., Saqib, M., Khan, M.S., Muhammad, G. and Rehman, S., 2018. Epidemiological study of mastitis in three different strains of beetal goat in selected districts of Punjab, Pakistan. Pakistan
Vet. J., 39: 389-394. https://doi.org/10.29261/ pakvetj/2018.118

Sarker, H. and Samad, M.A., 2011. Udder-halve-wise comparative prevalence of clinical and sub-clinical mastitis in lactating goats with their bacterial pathogens and antibiotic sensitivity patterns in Bangladesh. Bangladesh J. vet. Med., 9: 137-143. https://doi.org/10.3329/bjvm.v9i2.13456

Shamila-Syuhada, A.K., Rusul, G., Wan-Nadiah, W.A. and Chuah, L.O., 2016. Prevalence and antibiotics resistance of Staphylococcus aureus isolates isolated from raw milk obtained from small-scale dairy farms in Penang, Malaysia. Pakistan Vet. J., 36: $98-102$.

Silanikove, N., Leitner, G., Merin, U. and Prosser, C.G., 2010. Recent advances in exploiting goat's milk: Quality, safety and production aspects. Small Rumin. Res., 89: 110-124. https://doi.org/10.1016/j. smallrumres.2009.12.033

Thrusfield, M.V., 2007. Veterinary epidemiology. Blackwell Science, Oxford, Ames, Iowa. 